\title{
CULTIC PROPHECY IN THE PSALMS IN THE LIGHT OF ASSYRIAN PROPHETIC SOURCES ${ }^{1}$
}

\author{
John Hilber
}

\section{The Central Issue}

Since the early twentieth century, no consensus has been reached regarding the relationship between OT cultic prophecy and psalms, in particular, whether first-person divine speech in psalms originated from cult prophets or by poetic imitation of prophetic speech. Some have argued that spontaneous prophecy is incompatible with a fixed liturgical agenda and that the unified composition of psalms containing divine speech necessitates the composition of the whole prior to performance in worship, without the involvement of actual prophets. Assyrian prophetic sources ${ }^{2}$ attest to the existence of cult prophets in a culture relatively close to that of the OT, thereby inviting functional, form-critical, and thematic comparisons. Assyrian cult prophets announced divine support for the king, advocated the maintenance of temples and sacrifices, and offered divine response to inquiry and lament. These functions correspond to descriptions of prophets in the OT as voices of divine authority in royal affairs and as intermediaries who sometimes functioned at shrines. One might then expect psalms containing prophetic words that legitimise royal power (Psalms 2; 89; $110 ; 132$ ), advance cultic orthodoxy and practices (Psalms 50;68; 81; 95; 132) or address prayers and laments (Psalms $12 ; 60 ; 75 ; 82 ; 91$; 132) to arise from this setting, even as Assyrian cultic prophecy functioned in similar ways.

1 This is a summary of a Ph.D. thesis written under the supervision of Prof. Graham I. Davies at the University of Cambridge and defended in May 2004. The thesis will be published as "God Spoke in His Sanctuary" (Ps 60:8): Cultic Prophecy in the Psalms, BZAW 352 (Berlin \& New York: de Gruyter, 2005).

2 In particular, see S. Parpola, Assyrian Prophecies (State Archives of Assyria 9; Helsinki: University of Helsinki, 1997; hereafter abbreviated SAA) and M. Nissinen, References to Prophecy in Neo-Assyrian Sources (State Archives of Assyria Studies 7; Helsinki: University of Helsinki, 1998). 


\section{Comparison of Assyrian Prophecies and Psalms}

Assyrian prophecies find their closest counterpart in certain royal psalms, corresponding not only in form-critical style and thematic content but also in function. The form, style and function of Assyrian cultic prophecies (particularly SAA 9 2:4; 3:3; and SAA 9 7, but also Egyptian enthronement oracles) support the interpretation that Psalms 2 and 110 originated from prophetic speech in cultic enthronement ritual. While Psalm 132 does not correlate structurally with any single Assyrian oracle, the thematic and stylistic elements are similar. As in Psalm 132, Assyrian prophecy played a role in royal prayers, cultic initiatives and the unification of the political and religious spheres. Psalm 89 shares many themes (including royal lament) and phrases with Assyrian oracles, and the order of many elements corresponds to SAA 9 1:6.

The Asaphite psalms 50, 75, 81 and 82 (together with Psalm 95) contain framed, first-person divine speech as well as prophetic form and content. The common use of the divine self-identification formula in Assyrian prophecies associates the similar use in Psalms 50 and 81 with prophetic speech; and form-critical similarity between SAA 93 and Psalm 81 might support the prophetic origin of Psalm 81 in covenant renewal. Concern for cultic affairs among Assyrian prophets supports the idea that cultic exhortations in Psalm 50 are prophetic, not necessarily priestly. Both Psalm 50 and SAA $93: 3$ utilise theophany in the proclamation of divine self-identification. No form-critical correlations exist between Assyrian oracles and Psalms 75 and 82; however, thematic similarities support the argument that prophetic speech is the proper context in which to understand these psalms. The classification of Psalms 50 and 81 as 'sermons', whether Levitical or deuteronomistic, fails for lack of clear genre characterisation. On the other hand, the stylistic similarities with Assyrian prophecies point to an origin in cultic prophecy.

The role of Assyrian prophets as intermediaries in contexts of lament provides comparative evidence for a similar setting of Psalms 12, 60 and 91. Several form-critical and thematic elements also support this comparison. The unframed divine speech in Psalm 91 is particularly difficult; but blessing with didactic intent in response to prayer as well as shift in the person addressed is illustrated in Assyrian sources. 


\section{Cultic Prophecy, Psalm Composition and Performance}

There are several ways to envision the relationship between prophecy and psalmody that overcome objections to the incorporation of cultic prophecy in psalms and liturgical settings. These also find support in Assyrian prophetic sources. First, as Mowinckel suggested, a prophet scheduled to appear at a fixed point in worship could easily prepare in advance an address that would be appropriate to the context. A composition prepared in advance, to whatever degree, is not incompatible with genuine prophetic phenomena. Its original performance in worship classifies it as cultic prophecy (e.g., Psalms 110 and 2). A psalm composition could incorporate elements that were originally voiced by separate functionaries. Psalm 81 incorporates an extended prophetic speech on covenant fidelity (Ps. 81:5-17) as a response to a call to worship, possibly a festival celebrating the covenant (Ps. 81:2-4). This could involve two liturgists, the second being the prophet responding to the call; however, there is no reason a prophetic functionary could not announce both parts (see also Pss. 75:1-2/3-11 and Ps. 95:1-6a/6b-11). Even in some cases where there is intertextual unity between parts of the psalm, cultic prophecy delivered in the course of worship is still possible. For Psalm 132, a prophet might respond to the prayer of Ps. 132:1-10 with the corresponding words of Ps. 132:11-18, knowing in advance the outline of the prayer that would be offered. Second, a prophet's contribution to a psalm must not be restricted to first-person divine speech only. This consideration is important when there is tight intertextual unity between different parts of a psalm. Psalms 12, 50, 82, 89 and 91 present no difficulty for imagining a single prophetic composer and performer. Third, granting a high degree of rhetorical skill, a prophet might be able to address a situation at hand by spontaneous oral composition, in some circumstances echoing very closely the themes and phrases of other functionaries in the setting. Fourth, a psalm may contain a secondary prophetic citation; however, the source of that citation may have been the cult (e.g., Psalm 60 and its re-use in Psalm 108).

Assyrian prophecy makes a significant contribution to the question of cultic prophecy, textual composition, and subsequent performance of biblical psalms. Assyrian prophetic oracles displaying considerable rhetorical sophistication were delivered orally and immediately 
recorded in a temple setting. Even though Assyrian prophecies were deposited in the royal archive, they nevertheless illustrate a process whereby oral cultic prophecy became inscribed for future use. In the case of SAA 93, additional redactional activity is evident. Here, separate oracles from two different deities were collected on one tablet with liturgical instructions inserted. This is significant because it illustrates the movement from oral to written composition for the purpose of subsequent liturgical performance. Another significant example is SAA 313 , which illustrates the incorporation of cultic prophecy with royal prayer in what probably reflects a real cultic situation. Indeed, repeat performances of prophetic words could retain a degree of freshness (cf. Jeremiah 36). During repeated performances of Psalm 2, the divine words must have been construed as a fresh oracle able to renew divine legitimation of kingship, not unlike SAA 93. This suggests that a renewal festival might be the type of setting in which prophetic words originating in the cult could be re-used and performed by either a prophet or priest. Psalms 50, 81 and 95 are appropriate to this context, as is Psalm 132 to a festival involving the ark. Prophetic lament liturgies could be archived for appropriate use during difficult times in the life of the community or an individual (cf. Psalms $12 ; 60 ; 91)$. Assyrian cult prophets appear to have been on call for such occasions, and perhaps archived oracles served as exemplars for such service. Therefore, the possible scenarios of composition and performance are varied enough to accommodate prophecy in both liturgy and psalms.

\section{Diachronic Continuity of Cultic Prophecy}

Assyrian cultic prophecy in a real monarchic setting supports the position that some royal psalms also correspond to a monarchic (i.e., pre-exilic) setting. Psalm 89 may have been exilic. The genuine prophetic nature of the Asaphite psalms undermines the position that these are post-exilic priestly sermons. Psalm 12 is likely pre-exilic by virtue of its place in the first Davidic Psalter. Psalm 60 is suitable to a pre-exilic military context. Therefore, on the basis of Psalms evidence, cultic prophets were active in pre-exilic and exilic times. They may have re-emerged in the Second Temple. This is consistent with OT evidence from outside the psalms that there was a continuity of 
classical prophecy and that prophets were active in the cult before and after the exile.

\section{Conclusion}

Doubts about the contribution of cult-prophetic speech to psalmody remain in current debate. Examination of psalms containing firstperson divine speech has demonstrated their authentic prophetic character. Complementing the first-person divine speech are framing devices, formal structure, rhetoric, themes, as well as life settings, which conform to what ancient Israelite worshippers would have expected of actual prophetic speech. Alternative explanations of prophetic speech in psalms, such as the sermon or poetic imitation, lack comparable examples external to psalms. On the other hand, Assyrian cultic prophecies, arising from a culture not far removed from ancient Israel, parallel the characteristics of prophetic speech found in psalms. In addition, the Assyrian sources support possible composition and performance scenarios that overcome objections raised against the compatibility of genuine prophecy with psalmody. In conclusion, a model of cultic prophecy remains the best explanation for the origin of psalms containing first-person divine speech. 